3 Cellestis Ltd http://www cellestis com/IRM/ Content/gold/GOLD_USAPackagelnsert.pdf.

4 Shingadia D, Novelli V. Diagnosis and treatment of tuberculosis in children. Lancet Infect Dis 2003:3:624-32

5 ATS/CDC. Targeted tuberculin testing and treatment of latent tuberculosis infection. Joint Statement of the American Thoracic Society (ATS) and the Centers for Disease Control and Prevention (CDC) Am J Respir Crit Care Med 2000;161:S221-47.

6 Radhakrishna S, Frieden TR, Subramani R. Association of initial tuberculin sensitivity, age and sex with the incidence of tuberculosis in South India: a 15-year follow-up. Int J Tuberc Lung Dis 2003:7:1083-91.

7 Woldehanna S, Volmink J. Treatment of latent tuberculosis infection in HIV infected persons. Cochrane Database Syst Rev 2004; (1):CD000171.

8 Reznik M, Ozuah PO. Tuberculin skin testing in children. Emerg Infect Dis 2006;12:725-8.

9 Richeldi L, Ewer K, Losi M, et al. T cell-based tracking of multidrug resistant tuberculosis infection following brief exposure. Am J Respir Crit Care Med 2004; 170:288-95.

10 Ferrara G, Losi M, D'Amico R, et al. Use in routine clinical practice of two commercial blood tests for diagnosis of infection with

Mycobacterium tuberculosis: a prospective study. Lancet 2006;367:1328-34.

11 National Institute for Clinical Evidence. http:// www.nice.org.uk/

page. $\operatorname{aspx} ? \mathrm{o}=\mathrm{CG} 033 \mathrm{NICE}$ guideline.

\section{Heme oxygenase-1 gene promoter polymorphism and decline in lung function in Japanese men}

Chronic obstructive pulmonary disease (COPD) is characterised by progressive airflow limitation in the lung airway. Cigarette smoking is the most important risk factor for COPD. ${ }^{1}$ Heme oxygenase- 1 (HO- 1 ) is a key enzyme in heme metabolism and provides cytoprotection against oxidants in cigarette smoke. ${ }^{2}$ A $(\mathrm{GT})_{\mathrm{n}}$ dinucleotide repeat in the human $\mathrm{HO}-1$ promoter shows length polymorphism which is categorised into three groups: S-allele $(<27 \mathrm{GT}$ repeats), M-allele (27-32 GT repeats), and Lallele ( $\geqslant 33$ GT repeats). ${ }^{3}$ The L-allele was found to be associated with reduced $\mathrm{HO}-\mathrm{I}$ inducibility and susceptibility to pulmonary emphysema in a case-control study of Japanese male smokers. ${ }^{3}$ Conversely, He et al ${ }^{4}$ reported that $\mathrm{HO}-\mathrm{I}$ polymorphism was not related to a rapid decline in lung function in a prospective study of white smokers.

To evaluate the role of $\mathrm{HO}-\mathrm{I}$ polymorphism in the decline in lung function in Japanese subjects, 101 Japanese male ex-smokers with mild to severe COPD (forced expiratory volume in 1 second $\left(\mathrm{FEV}_{1}\right) \quad 40-90 \%$ predicted and $\mathrm{FEV}_{1} / \mathrm{FVC}<70 \%$ ) were enrolled from January 2000 to December 2001 and $\mathrm{HO}-1$ polymorphism was checked by PCR with peripheral blood DNA. Spirometric tests were performed at the beginning of the study and annually for 3 years. All participants sustained smoking cessation and were treated with bronchodilators including $\beta_{2}$ agonists and/or anticholinergic agents but not the long acting anticholinergic tiotropium. Rapid decliners are defined as subjects with a mean annual decrease in $\mathrm{FEV}_{1}$ of $\geqslant 3.0 \%$ predicted, ${ }^{1}$ whereas non-rapid decliners were subjects with a mean annual decline in $\mathrm{FEV}_{1}$ of $<3.0 \%$ predicted. Patients with active pneumonia, bronchial asthma, and malignant disease were excluded

There were 28 individuals with the L-allele (L-allele carriers) and 73 without the L-allele (non-L-allele carriers). The baseline characteristics of L-allele carriers and non-carriers did not differ (table 1). At the end of the follow up period there were 25 subjects with a rapid decline in lung function and 76 non-rapid

Table 1 Mean (SE) baseline characteristics and decline in lung function in L-allele carriers and non-L-allele carriers

\begin{tabular}{|c|c|c|c|}
\hline Characteristics & $\begin{array}{l}\text { L-allele } \\
\text { carrier } \\
\text { ( } n=28 \text { ) }\end{array}$ & $\begin{array}{l}\text { Non-L-allele } \\
\text { carrier } \\
\text { (n=73) }\end{array}$ & p value \\
\hline Age (years) & $70.3(1.7)$ & $70.6(0.9)$ & $0.84^{*}$ \\
\hline $\operatorname{Sex}(M / F)$ & $28 / 0$ & $73 / 0$ & $>0.99 * *$ \\
\hline \multicolumn{4}{|l|}{ Smoking status } \\
\hline No of ex-smokers & $28(100 \%)$ & $73(100 \%)$ & $>0.99 * *$ \\
\hline Pack-years & $44.7(4.6)$ & $49.3(3.6)$ & $0.47^{*}$ \\
\hline \multicolumn{4}{|l|}{ Pulmonary function } \\
\hline $\mathrm{FEV}_{1} \% \mathrm{FVC}$ & $59.6(1.4)$ & $61.0(1.0)$ & $0.83^{*}$ \\
\hline $\mathrm{FEV}_{1}$ (I) & $1.41(0.1)$ & $1.47(0.1)$ & $0.69^{*}$ \\
\hline $\mathrm{FEV}_{1}$ (\% predicted) & $62.6(4.8)$ & $65.7(3.3)$ & $0.61^{*}$ \\
\hline \multicolumn{4}{|l|}{ Treatment } \\
\hline Smoking cessation & $28(100 \%)$ & $73(100 \%)$ & $>0.99^{* *}$ \\
\hline Bronchodilator & $28(100 \%)$ & $73(100 \%)$ & $>0.99 * *$ \\
\hline \multicolumn{4}{|l|}{ Complications } \\
\hline Hypertension & $7(25 \%)$ & $15(20.5 \%)$ & $0.60^{* *}$ \\
\hline Diabetes mellitus & $3(10.7 \%)$ & $8(11.0 \%)$ & $>0.99^{* *}$ \\
\hline Hyperlipidaemia & $3(10.7 \%)$ & $5(6.8 \%)$ & $0.68^{* *}$ \\
\hline Cardiovascular disease & $5(17.9 \%)$ & $9(12.3 \%)$ & $0.52^{* *}$ \\
\hline Gastrointestinal disease & $6(21.4 \%)$ & $13(17.8 \%)$ & $0.78^{* *}$ \\
\hline \multicolumn{4}{|l|}{ Lung function decline } \\
\hline Decrease in $\mathrm{FEV}_{1}$ (\% pred) & $2.74(1.22)$ & $-0.57(0.89)$ & $0.044^{*}$ \\
\hline No of rapid declinerst & $12(42.9 \%)$ & $13(17.8 \%)$ & $0.009^{* * *}$ \\
\hline
\end{tabular}

All subjects had a smoking history of at least 10 pack-years and had quit smoking at least 6 months before the study. Lung function was assessed as post-bronchodilator values of spirometry.

*Unpaired $t$ test; ${ }^{* *}$ Fisher's exact test; ${ }^{* * *} \chi^{2}$ test.

†Rapid decline is defined as a mean annual decrease in $\mathrm{FEV}_{1} \geqslant 3.0 \%$ predicted.

decliners. The mean annual decline in $\mathrm{FEV}_{1} \%$ predicted in L-allele carriers was significantly larger than in non-carriers (mean (SE) 2.74 $(1.22) \%$ per year $v-0.57(0.89) \%$ per year, $\mathrm{p}=0.044$, unpaired $t$ test, table 1$)$. The proportion of rapid decliners was significantly higher among L-allele carriers than in non-L-allele carriers ( $12(42.9 \%) v 13(17.8 \%), \mathrm{p}=0.009, \chi^{2}$ test, table 1). Furthermore, the factors associated with a rapid decline in lung function were calculated by multivariate logistic regression analysis to adjust for potential risk factors including age, smoking status (pack-years), baseline $\mathrm{FEV}_{1}$ predicted, and L-allele carrier status. As a result, the adjusted odds ratio of Lallele carrier status for rapid decliners was 3.9 (95\% CI 1.4 to 10.6$), \mathrm{p}=0.009$ ( $12(48.9 \%)$ in rapid decliners $v 16(21.1 \%)$ in non-rapid decliners). Other factors were not significantly associated with a rapid decline in lung function.

The results of this study suggest that polymorphism of the HO-1 promoter gene may be associated with the rate of decline in lung function in Japanese male ex-smokers. A larger study is needed to confirm this result. Although the reason for the discrepancy between the results of our study and that of He et $\mathrm{al}^{4}$ is not clear, it might result from the difference in ethnic background of the participants. Since the susceptibility to COPD and/or decline in lung function could be influenced by a number of genetic and environmental factors, different polymorphisms in different ethnic groups may cause the same COPD phenotype. It is therefore important to confirm the associations of polymorphisms in each population. The L-allele carrier of the $\mathrm{HO}-1$ promoter gene in Japanese men is significantly associated with risks of developing lung adenocarcinoma, ${ }^{5}$ pulmonary emphysema, ${ }^{3}$ and less longevity. ${ }^{2}$ Modification of $\mathrm{HO}-1$ gene expression may offer a new target for therapeutic intervention in lung disease in the Japanese population.

\section{Acknowledgements}

The authors thank Mr Grant Crittenden for correcting the English.
K Nakayama, A Kikuchi, H Yasuda, S Ebihara, T Sasaki, T Ebihara, M Yamaya Department of Geriatric and Respiratory Medicine, Tohoku University School of Medicine, Sendai 980 8574, Japan

Correspondence to: Dr K Nakayama, Assistant Professor, Department of Geriatric and Respiratory Medicine, Tohoku University School of Medicine, 1-1 Seiryo-machi, Aoba-ku, Sendai, 980-8574, Japan kat-n@geriat.med.tohoku.ac.jp

The first two authors contributed equally to this work.

doi: $10.1136 /$ thx.2006.066423

Dr Nakayama was partly supported by a grant from the Japanese Foundation for Aging and Health of the Ministry of Welfare and Labor of the Japanese government. Dr Yasuda was partly supported by a Grant-In-Aid for Scientific Research from the Ministry of Education, Science and Culture (17790524) of the Japanese government. Dr Yamaya was partly supported by a Grant-In-Aid for Scientific Research from the Ministry of Education, Science and Culture (16590732) and the Ministry of Welfare and Labor of the Japanese government.

Competing interests: none declared.

\section{References}

1 Sandford AJ, Chagani T, Weir TD, et al. Susceptibility genes for rapid decline of lung function in the Lung Health Study. Am J Respir Crit Care Med 2001 163:469-73.

2 Shibahara S. The heme oxygenase dilemma in cellular homeostasis: new insights for the feedback regulation of heme catabolism. Tohoku J Exp Med 2003;200:167-86.

3 Yamada N, Yamaya M, Okinaga S, et al. Microsatellite polymorphism in the heme oxygenase-1 gene promoter is associated with susceptibility to emphysema. Am J Hum Gene 2000;66:187-95.

4 He JQ, Ruan J, Connett JE, et al. Antioxidant gene polymorphisms and susceptibility to a rapid decline in lung function in smokers. Am J Respir Crit Care Med 2002; 166:323-8.

5 Kikuchi A, Yamaya M, Suzuki S, et al. Association of susceptibility to the development of lung adenocarcinoma with the heme oxygenase-1 gene promoter polymorphism. Hum Genet 2005; 116:354-60. 